\title{
MENTORING: A FOCUS ON ETHNIC IDENTITY DEVELOPMENT AMONG AFRICAN AMERICAN MALE COLLEGE FRESHMEN IN THE DIGITAL AGE
}

\author{
John W. Hatcher III \\ Southeastern Louisiana University \\ SLU 10549, Hammond, LA. 70402, USA
}

\begin{abstract}
This study explored a process of mentoring African American males transitioning from high school to college. The researcher used Phinney and Ong's (2007) conceptualization and measurement of ethnic identity development employing the Multi-Group Ethnic Identity Measure-Revised survey. This research is intended to provide insight into the potential impact of mentoring on a group of African American male students who are navigating their first year of college, while discovering who they are. The use of digital sources assisted in the communication and relationship building processes that helped to support the mentorship effort. This is the initial phase of an ongoing study.
\end{abstract}

\section{KEYWORDS}

Mentoring, African American Males, Digital Age

\section{INTRODUCTION}

This study is significant as it will provide stakeholder groups with practical ways in which to engage African American male students in positive and supportive relationships, while guiding them towards graduation, as well as, their development of ethnic identity in the digital age. Identity development has been a challenge for African American males in the United States of America. Hatcher (2015) stated, "...these young males currently lead the nation [U.S.A.] in some of the most alarming statistics." These categories include, but are not limited to lower academic achievement rates, lower graduation rates, and higher dropout rates than their Caucasian and Asian counterparts (Brown, 2005 \& Fox \& Swatt, 2008). African American males are experiencing higher rates of homicides (Fox \& Swatt, 2008), while their life expectancy is declining (Anderson, 2006). These quality-of-life indicators highlight the ethnic identity development crisis among the African American male population.

Ethnic identity is a foundational aspect of one's identity, which is the critical crisis of Erik Erikson's (1968) fifth stage of human development (Identity versus Role Confusion). The underlying structures of Erikson's theory is that in each of the eight stages of development there are specific relationships that should develop, as well as, specific crises that needs to be resolved. The effective response to the identity question "who am I?" is predicated on the appropriate development of critical relationships and the resolution of the corresponding crises in each developmental stage. One of these critical relationships is that of the father's role in the child's development of their identity. However, Freek (2017) cited the absence of fathers as a major crisis and contributes to lower rates of academic achievement, increased behavioral problems, less motivation, and role confusion. The U.S. Census Bureau (2017) reported that almost two thirds of African American children under the age of 18 live in a households without a father figure. It is for this reason that the researcher focused on the role of the mentor in the process of ethnic identity development among African American male students using available technology to build and support respectful and trusting relationships. The origin of the term mentor has roots in the classical literature of Homer's Odyssey, in which, Mentor was left in Odysseus' stead to develop his son Telemachus, in Odysseus' absence. Mentoring is a fundamental form of human development where one person invests time and resources in support of the development of their mentee. Mentors today provide expertise to less experienced persons in order to enhance their 
education, advance their careers, and build supportive networks. "Mentoring can be defined as a significant, long-term, beneficial effect on a person's life or style, generally as a result of personal, one-on-one contact (www.aleanjourney.com)." The focus of mentoring in this study is to develop ethnic identity through the use of modern technology.

\section{BODY OF PAPER}

The researcher was assigned as the instructor and advisor to a college orientation course that every freshmen entering the host university must take. The purpose of the course is to support students while they are in the process of transitioning from high school into college and to advise them with regard to their scheduling, academic status, organizational interest, and overall navigation of their first year in college. The goal of the course is to increase the student's connection to the university through their advisor, in order to increase the retention rates and ultimately the graduation rates of all students. The purpose of this research was to report the initial findings of an ongoing process of mentoring. The instructor became the mentor and was responsible for building a positive and professional relationship with each student in order to support their successful transition. The class was made up of $n=(15)$ African American male students who were recruited as a convenient sample by the mentor during the summer prior to the start of their first semester of college. It is important to note that the instructor is an African American male educator with more than 25 years of experience in PreK-24 education. The class was scheduled to meet once a week for 16 weeks and for one hour and fifteen minutes each session. Given the amount of content for the course and the amount of time needed to build strong, positive, and appropriate working relationship with each student, the mentor initiated a mentorship effort to increase the amount of contact time with students. Mentoring can be a support for African American male student's success in college. Mentoring can have a tiered approach which includes adult-to-adult, mentor-to-student, and student-to-student, "mentoring approaches will create a supportive environment and community for the African American male that provides them with guidance and advice (Gardenhire, Cerna, \& Ivery, 2016)." The Sons of Promise Mentoring initiative employed each of the three types of mentoring relationships in order to create a viable support system for these college freshmen. Mentoring discussions can aid faculty members with the identification of at-risk students early in the semester (Pawley, 2018). Identification of student needs enables faculty to engage students with relevant advice, review of difficult concepts, and augment the course with the critical knowledge regarding their ethnic identity development.

\subsection{Ethnic Identity Development}

The underpinnings of this study are based in Erik Erikson's (1968) theory of psych-social development and Phinney's research on ethnic identity development. Erikson theorized that the primary journey in life is the development of individual identity and posits that identity development is the critical task of the adolescent stage of development. Erikson (1968) stated that identity development took place, "in the core of the individual and yet also in the core of his communal culture." It is essential to understand that ethnic identity is a type of individual or personal identity that influences all other aspects of identity. In the context of responding to the "Who am I?" question, the adolescent person must experience a sense of wholeness and congruence between that which he perceives about himself and what he believes others perceive about him (Erikson, 1968). Marcia's (1993) research bridges Erikson's eight stages of psycho-social developmental theory with Phinney's (1992) ethnic identity theory. Marcia extended Erikson's model of development by focusing on the adolescent stage of development and introduced four identity status groups.

Phinney (1992) developed the Multi-group Ethic Identity Measure survey instrument to measure ethnic identity status based on Marcia's (1966) study of identity in adolescence, wherein Marcia proposed the four stages of a linear process of identity development. Marcia (1993) would later modify his findings to reflect four status groups citing various pathways to connect to Erikson's fifth stage of psycho-social development, which is "Identity versus Role Confusion." The identity achieved status group has both committed to an identity and explored that same identity. This is the desired status group for resolving the crisis of identity. The moratorium status group has explored the meaning of a particular identity; however, they have not yet committed to that identity. The foreclosure status group, on the contrary, has committed to an identity 
without having explored that identity. This happens when an individual settles on an identity that has been projected upon them, yet they have not explored the whole of what is the meaning of that identity. The identity diffusion status group has neither committed to nor explored the proposed identity. The identity diffusion status group is considered to be in the state of an identity crisis or role confusion as Erikson put it.

Figure 1 is an illustration of how Phinney's theory assigned ethnic identity status groups. Phinney measured ethnic identity development status from the constructs of commitment and exploration. Phinney and Ong (2007) used a developmental approach to the study of identity development. Phinney and Ong stated: "We propose that a developmental approach, which focuses on the process of ethnic identity formation, can provide a theoretically and psychometrically sound basis for measuring the core aspects of ethnic identity" (p. 13). These two constructs are the basis for Phinney's study of ethnic identity development. The Multi-group Ethnic Identity Measure-Revised (MEIM-R) survey was administered to the class during the first month of class to measure each student's ethnic identity development status.

\title{
COMMITMENT
}
High
Low
High
ID Achievement
EXPLORATION

\begin{abstract}
Low Foreclosure ID Diffusion
Figure 1. The Four Ethnic Identity Statuses

The MEIM-R is made up of six items created to assess individual's commitment to and exploration of their ethnic identity. Three items assess the commitment construct and three items assess the exploration construct. Each item is rated on a five point Likert scale, one (1) was Strongly Disagree and five (5) was Strongly Agree. The mean score from each construct is calculated in order to determine a high or low rating and ethnic identity status.
\end{abstract}

\subsection{Mentoring in the 21st Century}

Researchers have reported that technology has changed the way people conduct their personal and professional relationships in very fundamental ways (Guy, 2002). There are still questions about whether technology has made measureable improvement to the quality of our relationships. Most people will agree that technology does have the potential to affect the quality of life for many people. Guy (2002) stated the following about mentoring in the 21st Century, "I explore the relationship of technology to mentoring through what is called tele-mentoring, the electronic version of mentoring (p. 27). He went on to further state that, "A key assumption that guides this exploration is that technology is altering the nature of human relationships, particularly mentoring relationships..." The researcher used a variety of technology applications to support and sustain his mentoring relationship with the student participants. Table 1 . illustrates the variety of technology applications used, the percentage of student participants who used that technology applications, and a brief description of the technology application.

Researchers say that educational aspects of mentoring include intervention, advising, and individualized development plans. Palmer, Davis, and Thompson (2010) observed intersectionality between building a community and mentoring where underrepresented students can become involved in the university. The various applications of technology were used in three main communication formats with and among the mentorship group. The formats used for whole group communication included Email and GroupMe. They were used to send notices, updates, and reminders to the entire group. The small group communication took place via Email, text message, Messenger, \& FaceBook and they were used for the same reason as whole group, yet with specific members of the group, such as, the leadership team. Phone calls, text message, FaceTime, Messenger, Messenger Games (Chess), and LinkedIn were all used in one-on-one communication between the mentor and an individual students. 
Table 1. Digital Resources Used for Communication

\begin{tabular}{|c|c|c|c|}
\hline Digital Application & $\begin{array}{l}\text { Percer } \\
\text { App. } t\end{array}$ & $\begin{array}{l}\text { tage of Students Using Tech. } \\
\text { Communicate (\#) }\end{array}$ & Description \\
\hline Email & 100 & (15) & Electronic mail application \\
\hline Phone Call & 100 & (15) & $\begin{array}{l}\text { A telephone communication } \\
\text { via telephone network }\end{array}$ \\
\hline GroupMe & 73.33 & (11) & $\begin{array}{l}\text { Group text messaging to } \\
\text { a set of telephones }\end{array}$ \\
\hline Text Msg. & 60 & (9) & $\begin{array}{l}\text { Text messaging, or texting, } \\
\text { composing and sending } \\
\text { electronic messages }\end{array}$ \\
\hline FaceTime & 26.67 & (4) & $\begin{array}{l}\text { a proprietary } \\
\text { Video- telephony product } \\
\text { developed by Apple Inc. }\end{array}$ \\
\hline Messenger & 26.67 & (4) & $\begin{array}{l}\text { is a messaging app } \\
\text { Videogames played by and }\end{array}$ \\
\hline Games (Chess) & 26.67 & (4) & between users \\
\hline Facebook & 20 & (3) & $\begin{array}{l}\text { an online social } \\
\text { media network }\end{array}$ \\
\hline LinkedIn & .67 & (1) & $\begin{array}{l}\text { a business service that } \\
\text { operates via websites and } \\
\text { mobile apps }\end{array}$ \\
\hline
\end{tabular}

\section{DISCUSSION}

In this study there were six (6) students who were rated in the Identity Achievement status group, five (5) who were rated in the Foreclosure status groups, and four (4) who were rated in the Identity Diffusion status group. In addition to the mentor who oversaw the group, the students rated in the Identity Achievement status group were mentored by upperclassmen. Student participants who were rated in the Foreclosure and Identity Diffusion status groups were guided toward adult mentors and mentors with greater experience. The additional mentors provided another layer of support for these African American male students who were in their first year of transition from high school into college. The additional volunteer mentors were all African American males. The mentoring initiative supported student's efforts to become involved in area of interest on campus as the lead mentor advised students to explore the university. The students' exploration allowed them to access the support systems that were available outside of their classroom. Examples were the Sons of Promise Mentorship Organization, which included adult mentors, such as, the Vice President of Student Affairs, the Dean of Students, and upperclassmen who became mentors. Exposure to activities on campus aided students with developing a relationship and commitment to the university. Braxton, Doyle, Hartley, Hirschy, Jones, \& McLendon (2014) stated that involvement while at the university leads to a subsequent commitment to completion of the student's degree. When seeking a model to describe human development through social interaction such as mentoring and especially social interaction in digital communication environments the notion of identity will often emerge. The researcher acknowledges that identity focuses on the individual's perceptions of self and ethnicity describes an individual's inclusion within a cultural group. The various digital applications enabled the lead mentor to nurture and maintain positive and supportive relationships with his students based on the technology available to each student, as well as, their individual preference to communicate. 


\section{CONCLUSION}

In the digital age much of one's identity has been reduced to creating profiles that include ethnicity, age, gender, interest groups, and sexual orientation, while ethnic identity development is explored through Google searches and documentaries found on Netflix. Online learning is taking place in both formal and informal settings. The use of technology in the classroom is used to assess student learning and has become commonplace, while Youtube has become the digital tutor and mentor for students in the digital age. This study explored the role of a mentor with regards to the development of ethnic identity through the use of various technology applications. Those who endeavor to become a mentor in the digital age must continue to engage face-to-face interactions; however, they must also be savvy in the use of technology applications that will support the types of communication that work for both the mentor and the mentee. The researcher in this study had to employ a variety of technology applications in order to build and maintain positive and supportive relationships with the student participants over the course of one year. Providing opportunities for students to explore their self-identifying ethnic identity has guided student participants toward answering the "who am I" question. The researcher will continue to investigate the ethnic identity of the participants in this study as they matriculate through their college experience. The MEIM-R survey will be administered each year students are in school in order to monitor participant's ethnic identity development status. Finally, follow-up interviews will be conducted to give voice to the African American male students participating in this ongoing study.

\section{ACKNOWLEDGEMENT}

I would like to acknowledge the Sons of Promise Mentorship Organization and every student participant who participated in this study. Your time, efforts, and continuous support aids the development of ethnic identity and improvement of academic achievement for those you serve. Thank you!

\section{REFERENCES}

Anderson J. L., 2006. An evaluation of African-American health status with gender comparison. California Journal Health Promotion, Vol. 4, No. 2, pp 168-174.

Braxton, J. M. et al, 2014. Rethinking College Student Retention. Jossey-Bass, San Francisco, CA

Brown, D.F. 2005. The significance of congruent communication in effective classroom management. The Clearing House, Vol.79, No.1, pp 12-15.

Cobb-Payton F., 2003.Rethinking the Digital Divide. Communications of the ACM, Vol. 46, No.6, pp 89-91.

Erikson E., 1968. Identity: Youth and crisis. Norton, New York, NY.

Fox J. et al, 2008. The recent surge in homicides involving young Black males and guns. Northeastern University, Boston, MA.

Freek F., 2017. Responding to the challenge of father absence and fatherlessness in the South Africa context: A case study involving concerned fathers from the North West Province. Stellenbosch Theological Journal. Vol. 3, No. 1, pp 89-113.

Gardenhire A. et al, 2016. Boosting college success among men of color: Promising approaches and next steps. Manpower Demonstration Research Corporation. Retrieved October 12, 2019 from https://www.mdrc.org/sites/default/files/MenofColor_b.pdf

Guy, T., (2002). Tele-mentoring: Shaping Mentoring Relationships for the 21st Century. Retrieved October 12, 2019 from http://www.calpro-online.org/eric/docs/mott/mentoring5.pdf

Hatcher J. et al, 2015. The African-American adolescent male identity development crisis: A mixed-methods design exploring the relationship between ethnic identity development status and student achievement. Journal of African American Males in Education, Vol. 1, No. 6.

Marcia J., et al, 1993. Ego identity: A handbook for psychosocial research. Springer, New York, NY.

McMahon T., 2016. Mentoring is Vital to Developing Lean Thinking. A Lean Journey. Retrieved October 12, 2019 from aleanjourney.com/2016/03/mentoring-is-vital-to-developing-lean.html 
Palmer R. T., et al 2010. Theory meets practice: HBCU initiatives that promote academic success among African Americans in STEM. Journal of College Student Development, Vol.51, pp 440-443.

Pawley A. L., 2018. Learning from small numbers: Studying ruling relations that gender and race the structure of U.S. engineering education. Journal of Engineering Education, Vol.108, pp 13-31.

Phinney J., 1992. The multigroup ethnic identity measure: A new scale for use with adolescents and young adults from diverse groups. Journal of Adolescent Research, Vol. 7, No. 2, 156-176.

Phinney J., et al, 2007. Conceptualization and measurement of ethnic identity: Current status and future directions. Journal of Counseling Psychology, Vol. 54, No. (3), pp 271-281.

Prince Z., 2016. Census Bureau: Higher Percentage of Black Children Live with Single Mothers. U.S. Census Bureau. Retrieved October 12, 2019 from afro.com/census-bureau-higher-percentage-black-children-live-single-mothers/ 